\title{
Microfinance Institutions through the lens of Social Entrepreneurship: Sri Lankan Experience
}

\author{
P. Uluwaduge \\ Faculty of Management and Finance \\ University of Colombo \\ R. Senathiraja \\ Faculty of Management and Finance \\ University of Colombo
}

\begin{abstract}
The objectives of the study are to explore the perception of Microfinance Institutes (MFIs) on Social Entrepreneurship (SE) and to examine the application of Positive Theory of Social Entrepreneurship (PTSE) in the MFIS in Sri Lanka and to identify unique social entrepreneurial characteristics in MFIs in Sri Lanka. This is a qualitative study carried out through primary data collected mainly from in-depth semi-structured interviews with 5 Chief Executive Officers (CEOs) representing 5 microfinance institutes in Sri Lanka who owned the largest microfinance loan portfolios. For the data analysis purpose thematic analysis method was used in the study. MFIs perceived the concept of social entrepreneurship as a social obligation parallel with profit making or as the obligation of the organization towards the society while achieving their commercial objectives. Application of the PTSE in the selected MFIs in Sri Lanka showed that four propositions on SE proposed in the theory can be observed to a considerable extent in the MFIs in Sri Lanka. Unique social entrepreneurial characteristics identified in the MFIs in Sri Lanka were adherence to the deep-rooted values of MFIs, much flexible approach when dealing with microfinance clients, impact from other stakeholders on MFI to perform social entrepreneurial role, and the co-operative model of MFIs tended to promote $S E$.
\end{abstract}

Corresponding Author:

Pradeep Uluwaduge, Ph.D. Student, Faculty of Management and Finance, University of Colombo. Email: pradeepu@lolc.com 
P. ULUWADUGE, R. SENATHIRAJA

\section{Keywords}

Social Entrepreneurship, Positive Theory of Social Entrepreneurship, Microfinance Institutes

\section{Introduction}

Under the umbrella of entrepreneurship, Social Entrepreneurship (SE) has been recognized as an emerging area of academic inquiry that needs further research (Sengupta, Sahay, \& Croce, 2017; Cukier, Trenholm, Carl, Gekas, 2011; Short, Moss, Lumpkin, 2009). The vitality of theoretical development on SE is evident, when searching for a proper definition to understand the concept of SE. Some broad definitions on SE such as "SE is an innovative activity with a social objective", often highlighted only two attributes of SE namely; creativity or the innovativeness and social objective (Dees and Anderson, 2003; Emerson and Twersky, 1996). Also, SE is defined abundantly as applying market-oriented skills in the non-profit sector (Reis, 1999; Thompson, 2002) and that would be due to the effort SEs make to generate a profit from an area which is generally believes as commercially not viable. Yet, some argued that, SE may take place in not-for profit organizations as well as in for profit companies, but the defining characteristic of social entrepreneurship versus business entrepreneurship is the creation of social wealth, not economic wealth (Cater, Beal and Collins, 2016). Furthermore, creating social value rather than the personal and shareholder wealth is characterized as a prominent feature of SE (Zadek and Thake, 1997; Santos, 2012). Also, the academic literature highlights two typologies regarding the understanding of SE; social orientation and socioeconomic orientation (Goyal, Sergi, and Jaiswal, 2016).

In Sri Lankan Microfinance (MF) sector, it can be evident that a notable growth of MFIs such as finance companies, banks and other institutes are venturing more than ever before, whose primary objective is profits (Lanka Microfinance Practitioners Association Review- LMFPAR, 2013).On the other hand, sustainable microfinance is known as the dramatic application of SE that achieves the status of "do well by doing good" where financial performance and social impact are dependent on each other not trade-offs between each other (Rosengard, 2004).This situation has created doubts as to whether Sri Lankan microfinance institutes which are social entrepreneurs in terms of social entrepreneurship theory.

Even though scholars have differentiated SEs from commercial entrepreneurs, a close scrutinize revealed that some of the demarcation between these two 
concepts are blurred. In terms of the mission of some commercial entrepreneurs, there may be a social mission while SEs anyway has a commercial purpose for its sustainability. Further, some commercial entrepreneurs create social value through the contribution to the society by producing goods and providing services, contribution to gross domestic production, creation of employment opportunities and etc. Thus, the fundamental differences of those concepts are not mutually exclusive.

Researches on SE have mainly focused on definition of SE and distinction of SE from commercial entrepreneurs, but few studies on application of SE (Hoogendoorn, Pennings, \& Thurik, 2010). Researches have not fully recognized the distinctive characteristics of SEs or the context of their actions and behaviours (Weerawardena \& Mort, 2006). Thus, evaluating of SE characteristics in a selected sector is indeed a challenging but a vital task.

The literature on SE too informed that, SE has a primary social purpose with a secondary commercial objective. To achieve that purpose organizations engage in business without distributing profits to individuals but reinvesting profits either in the same or new social venture and being accountable to the larger community it operates within (Pearce, 2003). Key concepts highlighted in the above definition have a strong link with the Positive Theory of Social Entrepreneurship (PTSE), which is applied in the selected microfinance industry in Sri Lanka. Accordingly, this paper intends to achieve following three research objectives:

To explore the perception of Microfinance Institutes on Social Entrepreneurship in Sri Lanka.

To examine the application of Positive Theory of Social Entrepreneurship in the MFIs in Sri Lanka.

To identify if any unique social entrepreneurial characteristics observed in the MFIs in Sri Lanka. 


\section{Literature Review}

A study of Senanayake (2003) recommended that Sri Lankan MFIs should take a more market-based approach replacing its charitable approach in order to alleviate poverty in the country. After more than a decade, situation has changed drastically and more profit-oriented MFIs have been performing social entrepreneurial role (LMFPAR, 2013). The change anticipated had taken place and however it is interesting to find out with that change how far these businessoriented MFIs have safeguarded their SE identity. In that sense this research will be helpful to understand the balancing act that is played by local MFIs

Further, this research will provide some insights to the MF practitioners on their approach and the direction they should be heading towards in the intensely competitive MF business environment. In terms of theoretical significance, this research will be helpful to further establish PTSE as a modern theory in the academic sphere with its application in the MF industry in Sri Lanka. Moreover, study reveals certain unique characteristics and models adopted by some of the MFIs considered for this study. Such institutes can be taken up for in-depth case study analysis to understand the dynamics of those characteristics and models for future researchers. To find out the role of MFIs in Sri Lanka in terms of the four propositions presented in the PTSE and accordingly to determine whether Sri Lankan MFIs can be categorized as social entrepreneurs. Since this particular area has been under researched intended research will bridge the prevailing literature gap as well.

\section{Defining Social Entrepreneurship}

A much broader understanding can be obtained through the comprehensive definition given by Light (2006) on SE as "an individual, group, network, organization, or alliance of organizations that seeks sustainable, large-scale change through pattern-breaking ideas in what or how governments, non-profits, and businesses do to address significant social problems". By stating few possible intervention areas that a social entrepreneur can engage in as SE, Bornstein and Davis (2010) provide a definition on SE as "a process by which citizens build or transform institutions to advance solutions to social problems, such as poverty, illness, illiteracy, environmental destruction, human rights abuses and corruption, in order to make life better for many". Succinctly the salient feature of the concept of SE is its mission to address social problems by mobilizing the organizational resources and there is no particular legal framework for SE to function and any form of institution can 
play the role of social entrepreneur whether public, business or nongovernmental organizations (Austin et al., 2006). Another important feature of $\mathrm{SE}$ is the intention for profit generation parallel to the social mission (Rosengard, 2004).

As articulated by Amudha and Banu (2009), MF is a strategy involves the provision of a broad range of affordable financial services to poor and lowincome households. Numerous researches have been conducted focusing on microfinance movements in the world whose initial intention was the poverty alleviation. MF was a prominent research domain for SE, since its mission was to focus on the poverty alleviation which is a burning social issue which cannot be combatted only by the government or non-profit organizations. Hence MF has gained a remarkable attention in the research domain of SE.

In Sri Lanka numerous government-initiated poverty alleviation efforts after and even before the independence of the country have been implemented (Senanayake, 2003). But in the recent past commercial entrepreneurs have ventured into MF business creating a severe competition and arousing a serious curiosity whether MF is a social entrepreneurship or a commercial entrepreneurship. However, according to the LMFPAR (2013), in Sri Lanka most of the MFIs consider poverty alleviation and entrepreneurial development as their key missions. Strong evidence can be found that Sri Lankan MFIs have given high priority to transform their borrowers to entrepreneurs as a sustainable poverty alleviation measure which ultimately falls within the domain of SE.

\section{Positive Theory of Social Entrepreneurship}

The role of SE to an economy of a country is very important in terms of its entrepreneurship generation at community level, job creation, poverty alleviation, directing limited resources towards neglected areas and many more. However, there is a huge vacuum in understanding the concept of SE and role of SE in the field of management (Dacin et al., 2010). Filipe M. Santos who is the founder of the "Positive Theory of Social Entrepreneurship" (PTSE) primarily intended to present a theoretical framework to understand the SE as an effort to bridge the said gap through his seminal work in 2012. Beyond, traditional economic and social value creation ideologies, Santos introduced concepts of "value creation" and "value capturing". Commercial entrepreneurships strive hard to capitalize on opportunities for value capturing while SEs look for an opportunity for value creation. However, these two concepts reinforce each other to have a sustainable venture. In other words, value capturing requires a 
value creation mechanism and sustainable value creation needs value capturing for its existence. Hence, all the entrepreneurial activities are trade-offs between those value creations and value capturing. Santos logically presents his theory through four propositions;

(i) Distinctive domain of action of social entrepreneurship is addressing neglected problems in the society involving positive externalities,

(ii) SEs are more likely to operate in areas with localized positive externalities that benefit a powerless segment of the population,

(iii) SEs are more likely to seek sustainable solutions than to seek sustainable advantages,

(iv) SEs are more likely to develop a solution built on the logic of empowerment than on the logic of control.

This study focused on the PTSE, which constructed upon four main propositions about SE (Santos, 2012). According to the theory, SE intervenes into the neglected problems in the society, SE operates in the areas of localized positive externalities, SE provides sustainable solutions for the identified problems and SE is capable of solving the problems by using the mechanism of empowerment rather than controlling. In the Sri Lankan MF industry, social performance management is increasingly becoming an integral part of MFIs (LMFPAR, 2013), other than the profit seeking goal of the organization. However, the MFIs are striving hard to achieve those contradictory goals simultaneously. Having considered those two objectives of the MFIs and four propositions presented in the PTSE, the study developed a conceptual framework is to identify the potential application of PTSE in selected MFIs in Sri Lanka.

Figure 1: Conceptual framework linking Positive Theory of Social Entrepreneurship with Microfinance Institutes

Positive Theory of
Social
Entrepreneurship
-Addressing neglected social
problems
-Internalize positive externalities
- Provisioning of sustainable
solutions
- Emnowerment

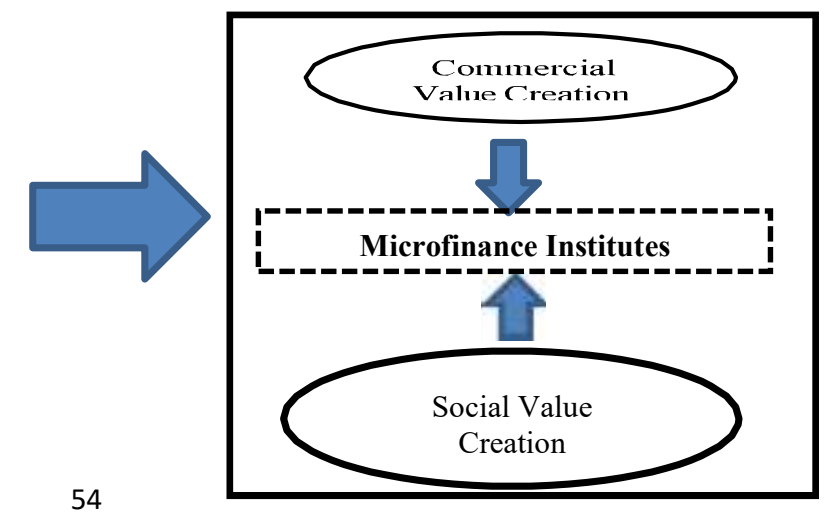


This qualitative study used both the primary and secondary data. Primary data collection was done through in-depth interviews. Since the area of study is quite new in the Sri Lankan context, usage of face-to-face in-depth interviews allowed the interviewees to make some clarifications from the researcher before responding to questions and also the researcher had the opportunity to dig deep in certain aspects. Secondary data was gathered through the annual reports of the companies, publications from the Lanka Microfinance Practitioners Association. The study population consists of approximately 50 formal sector MFIs took part in the annual microfinance survey as members of the Lanka Microfinance Practitioners Association between year 2013 and 2016 out of which 09 non-banking finance companies who are engaged in the MF business in Sri Lanka (LMFPAR, 2016). Selected sample contained 5 MFIs based on maintaining the largest microfinance loan portfolios in the country. The interviewees were 5 chief executive officers of those five companies. Thematic data analysis method used in the study.

\section{Brief Description about the selected MFIs of the study}

\section{MFI1}

MFI1 started its operation as an extension of their apex body which was the first NGO that started its operations in 1958 in Sri Lanka. Through the above moment, untapped social capital of the post-independent era was transformed into a vast community movement inspired by the Ghandian vision. Under that, number of societies were established and operated at village level under elected set of office bearers. They engaged in many social activities under the patronage of voluntary work of their members and the financial assistance of various donors. It was a long felt need that, the said movement should have its own financial services arm to expedite their social mission of expanding financial inclusion among the rural masses. The inception of financial arm was a natural process of evolution where the movement realized the importance of having its own economic arm and started it as a guarantee company.

Though this company limited by guarantee doesn't fall within the regulatory purview of Central Bank of Sri Lanka (CBSL), in 2010 they imposed rules to incorporate it as a finance company and apply for finance company license mainly because of the large deposit base they had and a sizable portfolio of microfinance lending. Today, MFI1 has reached over 60,000 micro customers with a total micro lending portfolio of Sri Lankan Rupees 2.5 billion through 
their 58 branches located island wide and with a total workforce of 600 . Even though this particular company has been forced to function as a typical finance company by the regulators today, still they are striving hard to secure their principles adopted at the inception of the movement.

\section{MFI2}

As per the CEO of MFI2, the mission of the institute was for merely a social cause and not for a commercial purpose. From the origin MFI2 has grounded on a pro-social entrepreneurial orientation. The founder of the movement who was a prominent socialist adopted very unique co-operative enterprise model focused on SE. Hence, the CEO interpreted their model as "a Social Enterprise nurtured by Corporative Enterprise". MFI2 was started in 1978 reinventing and re-engineering existing co-operative model which was a credit union introduced by the British. These co-operative societies were standalone savings or credit clubs, catering to a very limited segment of the society. Prominent figure in the field who fathered this movement, conducted research on various models and opted to adopt this unique co-operative model to execute his social entrepreneurial mission through this movement. The movement was registered as a public limited company in 1997 and as a licensed specialized bank by the CBSL under the Banking Act. MFI2 has reached over one million clients with over Sri Lankan Rupees 24 billion micro loan portfolio through their 89 branches in the country with total cadre strength of 1200 .

Through the system it was indicated that members' capital begins not only from finance but from social relationships among the members. Therefore, he intended to first develop the social capital and then to focused on financial capital. This can be seen as the uniqueness of this movement. Once the cooperative society was developed, it was at a better position to negotiate with those who had financial capital like banks and finance companies. Other uniqueness of this model is, unlike in typical microfinance model where finance companies approach clients, in co-operative model clients approach the cooperative society with a one common mission and a plan. The microfinance portfolio of MFI2 is less than $50 \%$ of its total lending portfolio of approximately Sri Lankan Rupees 52 billion.

\section{MFI3}

This was started its operations as a social entrepreneurial arm of a large conglomerate at that time. The chairman of the said conglomerate who was a 
leading businessman at that time-initiated measures to establish this movement with the primary motive of uplifting lives of rural poor people in Sri Lanka. He sent some of his staff members to Bangladesh to study the Grameen concept and they came and started the operations. Gradually with the operation they started making profits for their sustainability and growth. With that profit motive, they became the first commercialized MFI in Sri Lanka. The group which owned the microfinance operation underwent a financial crisis and another different investor outside the financial services sector invested in the company with $98 \%$ of holding and the company was registered as a public limited company under the Companies Act in 2010. Also, it was registered and started operations as a non-banking finance institute under the provisions of the Finance Business Act No 42 of 2011, in 2012. Incumbent managing director joined the company during that period and with the finance companies consolidation plan of CBSL, the MFI3 was acquired by a leading commercial bank in Sri Lanka. Interestingly $90 \%$ of company's lending portfolio consists with microfinance facilities, both individual and group lending and have reached over 250,000 micro clients so far through their 48 branches and 21 service centers, with a total cadre of 1200 . It is a clear indication that $M F I 3$ has been primarily focusing on microfinance facilities in line with its original mission. The CEO acknowledged the fact that regulatory interference has resulted in a clear mission drift when compared with its original mission.

\section{MFI4}

MFI4 was a non-banking financial institute that was aggressively driving microfinance products at rural level, mainly through group loan concept and through individual loans as well. It was established in 1982 as a registered finance company and with the change of management in 2009 under the leadership of present chief executive officer, company grew rapidly in the Sri Lankan financial services sector. The CEO who himself is the majority shareholder of the company was interviewed. When he was asked of his motive to move to microfinance sector, he said it is larger social mission more than profit. But when the researcher inquired him on its aggressive drive towards profits and higher yields from the microfinance related products, his argument was his company's purpose of existence is not making profits, but to achieve a larger social mission. Within a very short span of time they have reached total micro lending portfolio of over Sri Lankan Rupees 20 billion, with total cadre strength of 3500 . 
MFI5

MFI5 was operating as one of the few specialized microfinance companies in Sri Lanka. MFI5 was established in 2009 as a private company of a large conglomerate in Sri Lanka and has recorded a tremendous growth in its microfinance portfolio. Its primary objective is making profits while creating social value in its operations. When the directors of the company were in the view of starting the operation of a microfinance business, they were quite passionate about social value that they can create through the intended operations of a microfinance company. The CEO of the company emphasized the fact that, the whole group they were belonging to start triple bottom line approach with the operations. Out of its total portfolio of Sri Lankan Rupees 45 billion, about $40 \%$ is represented by their microfinance group loan and individual loan portfolios and they have reached over 200,000 clients through their over 130 branch network and with a total work force of 1000 .

\section{Data Analysis and Discussion}

This section analyses the data in the order of perception of MFIs on SE, the application of PTSE in the MFIs in Sri Lanka and the unique social entrepreneurial characteristics found in Sri Lankan MFIs.

\section{Perception of MFIs on Social Entrepreneurship}

All 5 interviewees of the study have stated that, their organizations are performing SE roles in a varied manner. Accordingly, it could be found similarities and dissimilarities of their perception on the concept of SE among the MFIs.

\section{SE as a Social Obligation}

However, the common perception all the interviewees had on SE in the MFIs was microfinance is a business with a social motive. They all have considered that, social entrepreneurial approach is an integral part in the MF because of almost the entire clientele of MFIs represents the grass root level poor people, who do not have access to the formal financial. Hence there is an ardent need of facilitating them with an extra support to develop those poor people not only in financial terms but in other means of empowerment as well. Thus, the interviewees stressed that, their companies always have the intention of supporting the clients by taking some extra efforts amidst of their profit motive which has become a part of their mandate. Consequently, interviewees stated 
that, MFIs are passionate about pursuing something socially valuable to the community. According to them, that is referred as SE. Some of the excerpts of the interviewees were as follows;

"SE is rendering a social service while engaged in a commercial cause" (MFII)

"Doing MF is supporting neglected part of people in the society. So, our main task is to address their needs and help them. That motivates us to do more socially valuable activities, which we consider as SE." (MFI2)

Another interviewee stated that, the concept of SE has been understood properly through the various practices of the organization over the years. In other words, the organization has been adopting a lot of socially valuable activities for a long period simultaneous with their usual microfinance business without realizing that they are performing the SE role by and large.

"In general, our company performs a variety of social activities which are important to the society apart from its core business. But we never realized that we were carrying out a social entrepreneurial role parallel with our business objectives. We felt it as an obligation that we have to perform when dealing with grass root level segments of the society." (MFI3)

\section{SE as a motive parallel with Profits}

The underline argument according to those excerpts implied that, the MFIs are driving along with dual objectives; profit making purpose and striving for social objectives as SE. Nonetheless, they have not mentioned that their priority is SE. Instead, they claimed that for the sustainability and the growth of the organization, profit is essential. Without adequate profit organization cannot be perpetuated. Moreover, it is accepted that sustainable microfinance companies are contributing more to the social objective more than other types of financial institutes (Jean and Klaus, 2009). On the other hand, generally they have considered organizations are established in the society for larger purposes rather than making profits. It may be the broader social purpose. From that stand, carrying out SE role would help the organizational sustainability, which is an obligation of the organization towards the society. It indicates that both the making profit and SE role are reinforcing each other for long term continuity of the MFIs. Some of the comments are: 
"For the organizational sustainability, it needs profit. Otherwise MFI cannot survive. But doing SE is something performing social responsibility which is also part and parcel of organizational sustainability." (MFI5)

"The organization exists for a larger social purpose. In their journey profit is a must for sustainability and growth. In order to realize larger social purpose, company has to make profits. Hence the profit is not the ultimate objective of the company." (MFI4)

MFI4 said profit is like food which is inevitable to continue our life, it is a must for a company to exist. Similar to purpose of our life is not to eat food. Profit should not be the purpose of existence of a corporate entity.

The findings revealed that MFIs are intertwined with SE role together with their main business motives. MFIs have considered that performing SE role as a social responsibility of the organization. Thus, sometimes they have not acknowledged and differentiated SE role as a separate function from their main microfinance activities. It may be because of the nature of the clientele they are working with. Succinctly, all the interviewed MFIs perceived SE as a "social obligation beyond profit making" of the organization towards the society. It is a significant fact that in the eyes of the leaders of the MFIs, SE is being considered as an obligation.

A similar nature of definition has been given on SE as "the use of entrepreneurial behaviour for social ends rather than for profit objectives" (Hibbert, Hogg and Quinn, 2005), highlighting the dual objectives of an organization. Cho (2006) explained SE as "a set of institutional practices combining the pursuit of financial objectives with the pursuit and promotion of substantive and terminal values." It describes the exact operation of MFIs considered in the study who are doing their microfinance business while creating social values.

\section{Application of Positive Theory of Social Entrepreneurship in the MFIs in Sri Lanka}

It has already been found in the literature that MF industry is widely popular for adopting SE in different manner. The extent of application of four propositions presented in the PTSE is examined under this section. 
Proposition 1 stated that SE is about addressing neglected social problems. The founders of selected MFIs of this study have identified prevailing poverty condition among rural masses as a critical social issue in the country that has not been able to resolve by the number of governments who were in the power after gaining independence in Sri Lanka. However, MFIs have seen numerous positive factors associated with that issue through their visionary thinking and passionate intention of providing a solution for the issue. They came up with various models to address the poverty and those organizations developed to larger movements in Sri Lanka. MFII which was an extension of a social movement and MFI2 which was founded as a co-operative model used their social service experience and same society models to operate MF operations as SEs. However, due to various factors those models went through lots of changes and still they claim that their original mission of founders is continued no matter what changes has taken place in their business models and the governing structures.

Even MFI4 and MFI5 claimed that their initial thought to venture into MF sector came up mainly due to the opportunity they identified in the society to serve those neglected masses in terms of their financial inclusivity and the opportunity for them to establish themselves as a well-grounded and profitable MFI at grassroots level of the country. Over and above the social service aspect of it, these two companies have looked at long term service they can offer for rural poor communities. Both the companies are catering to economically active poor segments of the society and they see a long-term potential in them as a viable sector that they can cater to at different levels of their financial status. Interestingly CEO of MFI4 argues that profit is a crucial thing to achieve at the inception and till the company establishes as a financially independent entity. Therefore, it is arguable whether initial tendency towards making profit by an MFI, perhaps for their sustainability is a disqualification to be branded it as a SE.

When the proposition 2 of the PTSE is considered, MFIs address issues with localized positive externalities among the powerless segments of the society. Especially, poor communities in the societies are mainly the target group of political parties to get into the power and when they want power, they tend to make various promises to eradicate poverty through various programmes if they are elected to power. Sri Lanka is no exception to such tendency and various poverty alleviation programmes have been implemented in Sri Lanka 
under different political parties after the independence with many attractive themes. Interviewees argued that none of these programmes had a clear vision to take targeted communities out of the poverty level. Hence opportunities were open for creative social entrepreneurs or private companies to come up with suitable programmes to address the social issues of these powerless segments of the society. All the companies that were considered for this study have understood this situation sufficiently and came up with their own programmes to address the same issue. Indeed, it was a benefit for these disadvantaged segments of the society to carry out something positively to get away from their poverty level. When they are gradually becoming financially stable, these programmes had made various financial products available for them to obtain based on the need. In that sense MFIs too had the opportunity to develop a longlasting rapport with these communities as a potential customer base that can be served on long term basis.

As described in the proposition 3 of the theory, 5 CEOs who were interviewed in the study have expressed that their long-term objective is to provide sustainable solutions rather than obtaining sustainable advantage through their MF operation. First three MFIs that were created at the inception itself for a social cause had that mission strongly embedded in their agenda. All the MFIs selected revealed that their positive and some innovative steps to implement sustainable solutions targeting the communities they cater with financial solutions. One of the key factors irrespective of their original mission was they were quite keen to facilitate economically active poor segment of the society who can be elevated to the next level quite conveniently compared with economically inactive segment who are living below the poverty line. As explained by the interviewees those MFIs make positive impacts on the lives of their borrowers by providing them with assistance by way of training and providing awareness and creation of markets to come up as entrepreneurs. Also, these MFIs have realized unless they make a sustainable solution, they won't be able to gain a sustainable advantage.

The proposition 4 is about empowering mechanism. MFIs considered in the study are mostly engaging in empowering rather than controlling their clients through the MF operations. Most of the lending takes place through group lending, individual lending or through societies with no collateral. All five MFIs practice a delegated authority level for staff members at different levels to carry out credit appraisals. Borrowers are too empowered in the MF sector to a greater extent with numerous supports from the MFI, compared with other 
financial lending activities. Apart from the staff and borrowers, other stakeholders too are empowered in the operations of these companies. As an example, societies are playing a pivotal role in the social value creation mission of MFI1 and MFI2 who are empowered to a greater extent to take investment decisions. Respective CEOs of both those MFIs took pride in explaining the success of some of their societies as financially independent entities with significant investments. Empowering is an inevitable factor for a successful SE role compared with commercial entrepreneurship where controlling is the main mode on which the operation is taking place as Michael Porter explained in his Five Force theory (Porter, 1980).

\section{Other unique Social Entrepreneurial Characteristics in the MFIs in Sri} Lanka

Despite the theoretically backed social entrepreneurial characteristics, some unique and interesting characteristics too were revealed in the MFIs in Sri Lanka when interviewing selected 5 CEOs of the study.

\section{Adherence to the deep-rooted values of MFIs}

MFII which was established as the financial arm of country's largest social movement, still adopts principles of its mother movement such as refraining from financing any project or business involving in animal slaughtering, selling of liquor, polluting the environment etc. Those virtues are deeply rooted in their organizational value system and the staffs from top to bottom have profoundly embraced them. Those types of ethical business would definitely bring merits to the society. Further MFI3 amidst of the acute competition strive hard to push borrowers to invest money in micro entrepreneurial activities, having their original missions in the value system.

\section{Much flexible approach when dealing with microfinance clients}

All the five MFIs chosen in the study adopt rather a flexible approach on defaulted MF clients compared to a defaulter of other finance facilities. CEO of MFI4 described it as "our objective is not to hurt our valued customers even when they have defaulted our loans. We jointly work with them to find out alternatives". This is a positive sign of the stance that MFIs have taken on their MF clients vis-à-vis other types of clients.

Further CEO of MFII and MFI3 elaborated the kind of soft stance they took when their MF clients got affected by natural disasters and how the staff of their 
MFIs went out of the way to help them out. It is an indication to understand the nature of social obligation these MFIs are performing. Further, when inquired of people empowerment, CEO of MFI4 stressed on the fact he uses empowerment to inspire his team members of the larger social mission they are involved with. Also, he accepted the fact that there are instances where the very same empowerment becomes a back lash such as frauds committed by the staff members misusing their given authority etc. But still he believes in empowerment as an effective tool to inspire the staff.

\section{Influence from other stakeholders to be Social Entrepreneurs}

CEO of MFI5 who claimed his company as the largest MFI operating in the country with majority of foreign funding, stated that the social entrepreneurial characteristics of his company is essential in attracting such large foreign funding at a competitive rate. As an example, he revealed that MFI5 is the only certified MFI in Sri Lanka with internationally recognized Client Protection Principles (CPP). Hence the pressure from external stakeholders too makes a positive impact on the MFI to take a pro-social approach in their businesses. However, he claims that now Client Protection Principles have become a part and parcel of their routine MF operation. Such unique client centric positive moves in the MF sector reiterate the fact that MF can no longer be treated as another mode of commercial entrepreneurship but as a social entrepreneurship.

\section{Co-operative Model of Microfinance Institutes}

One of the unique characteristics of the Sri Lankan MFIs is the co-operative model that coupled with the MF operation. Out of five MFIs chosen in the study, two companies are practicing this model, i.e. MFI1 and MFI2. The MFI2 has developed to be a leading specialized bank in the country through this unique model. CEO of the MFI2 emphasized that, "we first work towards creating social capital through societies and then the financial capital, once the social capital is established". This unique model has enormous positives such as collaborative efforts by the borrowers, accountability, individual support provided by the society. All those opportunities create a more stable path for individual borrowers to come out of their poverty with the support of other stakeholders in the society. Moreover, most of the MFIs in Sri Lanka are choosing Grameen model to launch their MF operations but pay limited attention to the locally introduced co-operative model. 
According to the CEO of MFI2, even though it was also operating under the co-operative model, its lending through societies is gradually diminishing with the shift of their focus on small and medium enterprises and individual lending.

Almost all the 5 MFIs selected had a positive response on the concept of developing entrepreneurs as a part of their MF operations. They accepted it as a fruitful way to break the poverty cycle. MFI5 reiterated that they had identified the potential areas for their borrowers to start a small-scale business and provide them with necessary training liaising through other governmental and nongovernmental institutes and issue them a certificate too. CEO of MFI3 revealed that their main targeted clientele is those who are currently engaged in some entrepreneurial activity and approximately $60 \%$ of their clients have developed as entrepreneurs and have been graduated to the next level of financial facilities by the MFI. All the MFIs in the study had to share success entrepreneurial stories that they have nurtured. Those stories have become a strong indication of social entrepreneurial role played by the MFIs operated in Sri Lanka.

\section{Conclusion}

This study intends to achieve three objectives of exploring the perception of MFIs on Social Entrepreneurship, examining the application of Positive Theory of Social Entrepreneurship in the MFIs in Sri Lanka and identifying any unique social entrepreneurial characteristics in MFIs in Sri Lanka. The study revealed that Sri Lankan MFIs have numerous embedded social entrepreneurial characteristics in varying degrees. Interestingly it was found that some MFIs have been initiated with social entrepreneurial missions. Nonetheless, MFIs perceived SE is a social obligation which goes parallel with profit making motive. Founder's leadership role of MFI is pivotal, and their founding philosophy has been implanted as the vision of the MFI which is a driving force in pursuit of SE mission.

Application of the PTSE in selected MFIs in Sri Lanka showed that four propositions on SE proposed in the theory can be observed to a considerable extent in the MFIs in Sri Lanka. MFIs in Sri Lanka take into consideration social problems that are not addressed by the other organizations such as poverty alleviation efforts, entrepreneurial development. MFIs look for opportunities in the society for value creation through providing sustainable solutions and empowering MF clients and MF staff. 
Unique social entrepreneurial characteristics identified in the MFIs in Sri Lanka were adherence to the deep-rooted values of MFIs, much flexible approach adopted when dealing with MF clients compared with other types of clients, impact from other stakeholders on MFI to perform social entrepreneurial role, and co-operative model of MFIs tended to promote SE.

\section{Managerial Implications and Future Directions}

This study derives implications for entrepreneurs, managers and profit seeking organizations. Perception among the chosen five MFIs on SE as a social obligation of the organization in parallel with making profits indicated that even profit seeking organizations tend to have a sense of giving more to the society, particularly for those who are in need of assistance yet neglected by the society. Hence, profit seeking organizations can convert those neglected societal needs into profit making avenues by introducing new products and services. Further, as elaborated in the proposition 4 of the PTSE theory and reflected by the findings of the study, SE is a powerful empowering tool that can be used to create multiple benefits for the whole society. Through that, organizations are able to satisfy their customers and other stakeholders while maintaining organizational sustainability.

However, to have a deeper understanding on SE in MF industry and to validate the social entrepreneurial role of MFIs can be done through further examining the perception of MF clients on the role of MFIs in Sri Lanka. 


\section{References}

Alvord, S. H., Brown, D. L. and Letts, C. W. (2004), "Social entrepreneurship and societal transformation: An exploratory study", Journal of Applied Behavioural Science, Vol.40, pp.260-282.

Amudha, R and Banu, C.V.,(2009), "Micro Finance - A Tool for Elevation of Social Entrepreneurship through Women Empowerment", Asia Pacific Business Review, 5 (1), pp.77- 86 DOI: 10.1177/097324700900500109

Austin, J., Stevenson, H. and Wei-Skillern, J. (2006), "Social and Commercial Entrepreneurship: Same Different, or Both", Entrepreneurship Theory and Practice, Vol. 30, pp. 1-22.

Berma, M. and Kasim, M. Y. (2004), "Social Capital and Poverty Alleviation" in Malaysia, in Hasan, S \& Onyx, J (eds) Social Capital and Sustainable Development Management: Lessons from Asia, NY: Nova Science Publishers.

Bonfanti, A., Battisti, E. and Pasqualino, L. (2016)," Social entrepreneurship and corporate architecture: evidence from Italy ", Management Decision, Vol. 54 Iss 2 pp. $390-417$.

Bornstein, D. and Davis.S. (2010). Social Entrepreneurship: What Everyone Needs to Know. Oxford: Oxford University Press.

Cater, J.J., Beal, B.D. and Collins, L.A. (2016)," The changing paradigm of fair trade social entrepreneurship in the United States ", Management Decision, Vol. 54 Iss 7 pp. 1732-1756, doi: http://dx.doi.org/10.1108/MD-01-2016-0029.

Cho, A. H. (2006), "Politics, values and social entrepreneurship: A critical appraisal", In J. Mair, J. Robinson \& K. Hockerts (Eds.), Social entrepreneurship, pp34-56.

Cukier, W., Trenholm, S., Carl, D., Gekas, G. (2011). "Social Entrepreneurship: A Content Analysis", Journal of Strategic Innovation and Sustainability, Vol. 7, No.1, pp. 99-119. 
Dacin, P.A., Dacin, M.T., and Matear, M. (2010), "Social Entrepreneurship; why we don't need theory and how we move forward from here", Academy of Management Perspectives, Vol. 24, No. 3, pp. 37-57.

Daphne W. Y., William P. W., Frank W. N., Ng C. and Jun, S. (2014), "Sentimental Drivers of Social Entrepreneurship: A Study of China's Guangcai (Glorious) Program", Management and Organization Review, Vol. 10, No. 1, pp. 55-80.

Dees, J. G. (1998), "The meaning of social entrepreneurship". Retrieved from; http://www.redalmarza.cl/ing/pdf/The Meaning of social Entrepreneurship.pdf (accessed, May 2, 2016)

Dees, J.G. and Anderson B.B. (2003). "For profit social ventures", International Journal of Entrepreneurship Education (special issue on social entrepreneurship), Vol. 2, pp. 1-26.

Dees, J.G. (2012), "A tale of two cultures: charity, problem solving, and the future of social

Entrepreneurship", Journal of Business Ethics, Vol. 111 No. 3, pp. 321-334.

Emerson, J. and Twersky, F. (Eds). (1996), "New Social Entrepreneurs: The Success, challenge and lessons of non-profit enterprise creation". San Francisco: Roberts Foundation, Homeless Economic Development Fund.

Goyal, S., Sergi, B.S. and Jaiswal, M.P. (2016)," Understanding the challenges and strategic actions of social entrepreneurship at base of the pyramid ", Management Decision, Vol. 54 Issue 2 pp. 418 - 440, doi: http://dx.doi.org/10.1108/MD-11-2014-0662

Hibbert, S., Hogg, G., and Quinn, T. (2005), "Social entrepreneurship: Understanding consumer motives for buying The Big Issue", Journal of Consumer Behaviour, Vol. 4, No. 3, pp. 159-172.

Hoogendoorn, B., Pennings, Eand Thurik, R., (2010) "What Do We Know About Social Entrepreneurship? An Analysis of Empirical Research”, Erasmus research institute of management (ERIM), report series-research in management, 3rdversion: June 2010pp. 01-39 
Gueyié, J.P. and Fischer, K.P. (2009), "Microfinance and Market-Oriented Microfinance Institutions", Canadian Journal of Development Studies, Vol. 29, pp. 23-39.

Jean P.G and Klaus P.F., (2006), "microfinance and Market oriented microfinance institutions", Canadian journal of development studies, 29, nos.12 pp. $23-40$

Julian G., and Emmanuel R. (2014), "Extreme poverty alleviation through community-based entrepreneurship: PRODECO in Paraguay", Development in Practice, Vol. 24, No. 1, pp.140-146, doi:10.1080/09614524.2014.867301. 24

Lanka Microfinance Practitioners' Association, (2013), Microfinance ReviewSri Lanka, Performance \& Analysis Report, Lanka Microfinance Practitioners' Association.

Light, P. (2006). Reshaping social entrepreneurship. Stanford Social Innovation Review, 47-51.

Mair, J., and Martı', I. (2006), "Social entrepreneurship research: A source of explanation, prediction, and delight", Journal of World Business, Vol. 41, No. 1, pp. $36-44$.

Oster, S.M. (1994), Strategic management for non-profit organizations: theory and cases. New York: Oxford University Press.

Pearce, J. (2003), Social Enterprise in Any Town, Calouste Gulbenkian Foundation.

Porter, M. (1980). Competitive Strategy. New York: The Free Press.

Reis, T. (1999), Unleashing the new resources and entrepreneurship for the common good: A scan, synthesis and scenario for action, Battle Creek, MI:

W.K. Kellogg Foundation.

Roberts, D., and Woods, C. (2005), "Changing the world on a shoestring: The concept of social entrepreneurship", University of Auckland Business Review, Autumn, pp. 45-51. 
Rosengard, J. K. (2004), "Banking on Social Entrepreneurship: The Commercialization of Microfinance", Mondes en Développement, Vol. 32, No. 2, pp. 25-36.

Ruiz, J., Soriano, D.R. and Coduras, A. (2016), "Challenges in measuring readiness for entrepreneurship", Management Decision, Vol. 54, No.5, pp. 1022 -1046 .

Santos, F.M. (2012), “A Positive Theory of Social Entrepreneurship", Journal of Business Ethics, Vol.111, pp. 335-351.

Seelos, C., and Mair, J. (2005), "Social entrepreneurship: Creating new business models to serve the poor", Business Horizons, Vol. 48, pp. 241-246.

Sengupta, S., Sahay, A. \& Croce, F. (2017). "Conceptualizing social entrepreneurship in the context of emerging economies: an integrative review of past research from BRIICS", International Entrepreneurship and Management Journal. DOI: https://doi.org/10.1007/s11365-017-0483-2

Senanayake, S. M. P. (2003), "Some critical issues relating to the commercialization of micro finance institutions in Sri Lanka", Savings and Development, Vol. 27, No. 1, pp. 79-95.

Short, J. C., Moss, T.W., Lumpkin, G.T., (2009), "Research in Social Entrepreneurship: Past Contributions and Future Opportunities", Strategic Entrepreneurship Journal, Vol.3, No. 2, pp.161 - 194.

Stevenson, H.H., and Jarillo, J.C. (1991), "A new entrepreneurial paradigm" in A. Etzioni and P. Lawrence (Eds), Socio-economic: Towards a new synthesis (pp.185-208). Armonk, NY: M.E. Sharpe.

Thompson, J. (2002), "The world of the social entrepreneur", International Journal of Public Sector Management, Vol. 15, No. 5, pp. 412-431.

Tripsas, M. (2009), "Technology, identity and inertia through the lens of the digital photography company", Organization Science, Vol. 20, No.2, pp. 441460 . 
Waddok, S.A. and Post, J.E. (1991), "Social Entrepreneurs and Catalytic Change", Public Administration Review, Vol. 51, No. 5.

Weerawardena, J and Mort G.S., (2006) "Investigating social entrepreneurship: A multidimensional model" Journal of World Business 41,pp. 21-35

Yapa, L. (1998), "The Poverty Discourse and the Poor in Sri Lanka", Transactions of the Institute of British Geographers, Vol. 23, No. 1, pp. 95-115.

Zadek, S., and Thake, S. (1997), Send in the social entrepreneurs. New Statement, 26, 31.25

Zahra, S. A., Gedajlovic, E., Neubaum, D. O., and Shulman, J. M. (2009), “A typology of social entrepreneurs: Motives, search processes and ethical challenge", Journal of Business Venturing, Vol. 24, No. 5, pp. 519-532. 